\title{
Does the effect of power distance moderate the relation between person environment fit and job satisfaction leading to job performance? Evidence from Afghanistan and Pakistan
}

\author{
Habib Gul ${ }^{\mathrm{a}}$, Muhammad Usman ${ }^{\mathrm{a}}$, Yuxin Liu ${ }^{\mathrm{a}}$, Zahid Rehman ${ }^{\mathrm{a}}$, Khalil Jebran ${ }^{\mathrm{b}, *}$ \\ ${ }^{a}$ Business School, University of International Business and Economics, Beijing, China \\ ${ }^{\mathrm{b}}$ School of Accounting, Dongbei University of Finance and Economics, Dalian, China
}

Received 3 July 2017; received in revised form 23 November 2017; accepted 28 December 2017

Available online 8 January 2018

\begin{abstract}
This study examines the relation between person-environment (P-E) fit with job satisfaction and job (task) performance. This cross-national study is based on faculty members of universities from Kabul (180) and Islamabad (270). Data is collected through self administered questionnaires and is tested following the Baron and Kenny (1986) moderation and mediation procedures. The studycontend that power distance moderates the relationship between P-E fit and job satisfaction. Contrary to expectation, power distance does not moderate the hypothesized relationship. This study finds that individual's satisfaction from high power distance culture depends on their cultural norms because they give more preference to cultural norms than their own needs and demands. Moreover, results show the direct relationship of P-E fit with job performance in Afghanistan (Kabul) and Pakistan (Islamabad). We compared the results of hypothesized model cross-nationally and find some variation regarding employee's job satisfaction. Job satisfaction partially mediates the relationships between P-E fit and job performance in Kabul, while in Islamabad job satisfaction fully mediate the relationship between P-E fit and job performance. By asserting the role of culture, this study developed practical implications for both theorists and practitioners.

(c) 2018 Faculty of Commerce and Business Administration, Future University. Production and Hosting by Elsevier B.V. This is an open access article under the CC BY-NC-ND license (http://creativecommons.org/licenses/by-nc-nd/4.0/).
\end{abstract}

Keywords: P-E Fit; Power distance; Job satisfaction; Job performance; Afghanistan; Pakistan

\section{Introduction}

The selected countries (i.e. Afghanistan and Pakitan) labor market is facing serious challenges such as, lack of knowledge, skills, and abilities because of the political instability, the insurgencies, law and order situations from the last three decades specially Afghanistan is affected more than any country in the world. The lack of unskilled or misfit have serious detrimental consequences both for the organization and the employees (Lee \& Ramaswami, 2013). Therefore, a match or compatibility between the environment and the situation is essential. Person environment (P-E) fit is a construct that has achieved a lot of consideration from scholars and practitioners to understand the attitudes and behaviors at workplace since last two decades (Bednarska, 2017; Lee \& Antonakis, 2012; Edwards, 1991; Kristof,

\footnotetext{
*Corresponding author.

E-mail address: khaliljebranuom@gmail.com (K. Jebran).
} 
1996; Nolan \& Morley, 2013). Psychological theory of work adjustment proposed that the congruence between employee's attributes and those of the workplace leads to attitudinal and behavioral outcomes (Dawis \& Lofquist, 1984). The fundamental concept of P-E fit is the psychological mechanism of compatibility that has been mimicked from similarity and need fulfillment (Kristof-Brown \& Guay 2010). Thus the psychological development plays a significant role to enhance culture (Lehman, Chiu, \& Schaller, 2004). P-E fit can vary from culture to culture; there is still a debate among researchers to explain this extant effect of P-E fit on numerous attitudinal and behavioral outcomes.

The construct of P-E fit is appealing for examining the cultural effect over a decade (Schneider, 2001). However, there are limited empirical studies about the generalizability and the validity of P-E fit across cultures (Kristof-Brown \& Guay, 2010). Hence, one of the major objectives of the current study is to generalize the concept of fit. In line with previous studies suggestions, the current study has taken power distance as a moderator between the relationship of P-E fit and job satisfaction, which is consistent with the studies of Lee and Antonakis (2012). They found that employees in a higher power distance culture will be happy if they get what they desire. However, if their preferences are not fulfilled according to the social norms and values beside a high level of fit the individual will be dissatisfied. Moreover, based on the previous findings we assumed that culture might play a significant role between P-E fit and job satisfaction in a novel context. These findings are generally failed to report for the effects of cultural values on psychological mechanism that ultimately effect on employee behaviors (Lehman et al., 2004). In addition, we found an interesting analogy for our assertion on the moderating effect of power distance as below.

P-E fit research, especially with its focus on personal affective outcomes, is definitely a western tradition, dominated by an emphasis on the individual and on personal satisfaction. These are clearly not universal values and so at least one other the equation environmental variable, national culture, must enter the equation for P-E fit research. It must but has not (Schneider, 2001. p. 148).

Job satisfaction is defined in many different ways. However, the most authentic definition is that of Locke (1969) "Job satisfaction is a positive or pleasurable reaction resulting from the appraisal of one's job, job achievement, or job experiences" (p.317). The employees' job performance is the consequence or result of the individual's behavior (Sonnentag and Frese, 2002). Furthermore, Bartram (2005) found that employee's having good knowledge of their job are expected to perform their job successfully. The plethora of research supported the notion that a good fit between employees and their environment have positive consequences for the individual and the organization. For example, this notion is lately confirmed from the meta-analysis of (Oh et al., 2014; Kristof-Brown, Zimmerman, \& Johnson, 2005) that P-E fit is strongly associated with individual outcomes described by prospective employees. Similarly, empirical analysis found that employee's are found satisfactory, committed with their jobs because of a mutual fit between the characteristics of his own and requirements of the organization (Oh et al., 2014; Mulky, 2012).

Triandis (1994) emphasized on the cross-cultural perspectives of the research and described that, the theories that are presented in western developed countries which make $30 \%$ of the world population and findings of these theories are implementing on the remaining world $70 \%$ population. Addressing the need for cross-cultural studies on P-E fit notion, Lee and Ramaswami (2013) described that "efforts to provide a cultural perspective on fit are rather scant or invisible" (2013). To address this cross-cultural issue in fit research, the current study examined the relationship between P-O fit and P-J Fit and job satisfaction leading to job performance, and further it explain why this particular relationship occur. Perception of P-O Fit and P-J fit are essential for enhancing employee attitudinal and behavioral outcomes (Cable \& DeRue, 2002), therefore in this model P-O fit and P-J fit enhancing employee job satisfaction and job performance in a novel context. To examine this particular proposed relationship, we tested the model by using teachers samples from Afghanistan $(n=180)$ and Pakistan $(n=270)$. The Afghanistan and Pakistan have mostly similar culture practices but are mostly neglected in organizational research. This difference between the cultures has the vantage points for understanding the proposed model of fit. First, as according to Aycan et al. (2000) Pakistan is under research country, whereas Afghanistan is considered among the least research countries. So the main objective of the study is to analyze the level of fit and its relationship with attitudinal and behavioral outcomes among the university teachers of Pakistan and Afghanistan. Secondly, the universities are providing a high level of education to the community so there is a need to have congruence between a high level of fit between the teacher and their job and also with their organization. According to MOHE Afghanistan (2013) less than 2\% of the current university teachers have Doctoral degrees and $36 \%$ have MS/MPhil. This may affect the capability of individuals to deliver the forecasting accepted results due to lack of misfit (Aris, 2007). Thirdly, the differences in culture between the two countries are indicated in the results in organizational settings (Hofstede \& Hofstede, 2005), it can effect on the fit- 
outcome relationships. A meta analysis of Oh et. al. (2014) suggests that P-J fit and P-O fit effects are stronger then East Asian context. However, person-group fit and person-supervisor fit (relational fit) have stronger effect in East Asian context. So in a high power distance culture where people give preference to relational fit, which dimension of P-E fit is more salient in Asian context. Results concerning fit on job performance are less clear in such context.

Furthermore, this study is focusing on the question that "how P-E fit influences job satisfaction and job performance in high power distance cultures". Prior studies found that teacher's knowledge, abilities and interest are pre-conditions for professional development and their prospective, job satisfaction and job performance (Nye, Su, Rounds, \& Drasgow, 2012; Swanson, 2012; Kristof-Brown \& Guay, 2011). Nevertheless, considering teacher's P-E fit at workplace requires essential personal characteristics, but this is also an objective of every organization to have a maximum mutual congruence. Therefore, the fundamental assumption is that both employees and the organization will be more triumphant, if the characteristics of individual's and those of the organization are highly congruent with each other's (Ostroff, 1992). By examining the consequences of P-E fit in academia, this may help not only in extending the psychological studies in higher education institution but it will also help for the organization effectiveness. We hope that this study will also fulfill the call by Schneider (2001) who recommended that "the inclusion of culture should be the start of a new tradition" (p. 141) in the fit research. In addition, examining this proposed model of fit cross-nationally contributes both to the generalizability of the fit research in South Asian context as well as extending culture, job satisfaction and job performance literatures.

\section{Theoretical underpinning and hypothesis}

P-E fit has been defined as "the compatibility between an individual and a work environment that occurs when their characteristics are well matched" (Kristof-Brown \& Guay, 2010). Prior studies on fit distinguished between personorganization (P-O) fit and person-job (P-J) fit. P-O fit refers to the congruence between individual's values and that of organization's culture, while P-J fit refers to the congruence between an individual's knowledge, skills and abilities and the requirements of a job (Kristof-brown, 2000). According to Carless (2005) P-E fit is the combination of P-J fit and P-O fit. Later on Edwards (2008) suggested that P-O fit and P-J fit are the two major representative dimensions of P-E fit. These two dimensions are useful when the focus of the study at workplace is in-role behavior as mentioned in job description (Cable \& DeRue, 2002). In addition from an organizational perspective, these two dimensions under the umbrella of P-E fit are considered as important because it stresses on the evidence that successful individuals must be fit with organization and their job (Iplik, Kilic, \& Yalcin, 2011; Kristof-brown, 2000; Lauver \& Kristof-Brown, 2001).

\subsection{P-J fit}

Examining the interaction between the employees and their workplace is prominent in P-E fit model ( D'Amato \& Zijlstra, 2008). P-J fit refers to the "job or the certain set of functions required for a given position. If a person has the abilities necessary to perform the requisite tasks effectively or the job meets that individual's needs, then a good P-J fit exists" (Kristof-Brown, Jansen, \& Colbert. 2002, p.985). Edwards (1991) quantified into need-supply fit and demand ability fit, the prior refers to "employee desires and job supplies available to meet those desires" (Edwards, 1991, p.285), while the later has been defined as the "job demands and employee abilities available to meet those demands" (Edwards, 1991, p.285).

P-J fit is based on the assumption both theoretically and empirically that P-J fit leads to employee job performance, job satisfaction and organizational commitment (Ostroff, Shin, \& Kinicki, 2005; Bartram, 2005; Edwards \& Shipp, 2007). Later on other studies also found that P-J fit is positively correlated with employee-job satisfaction (Li \& Hung 2010; Saks \& Ashforth, 1997). Furthermore the strength of this proposed model has the ability to explain human behavior as a product of association between employees and environment (Lewin, 1935, Kristof, 1996).

Similarly according to psychological theory of work adjustment, Dawis and Lofquist (1984), which assumed that if the psychological needs, desires, and preferences are fulfilled in a better way, this will result in a favorable attitudinal and behavioral outcome for the organization. So based on aforementioned theoretical findings, the study has proposed the following hypothesis:

H1. : There is a significant positive relationship between P-J fit and employee job performance. 
H2. : There is a significant positive relationship between P-J fit and employee job satisfaction.

\section{2. $P-O$ fit}

P-O fit refers to the match between an employee values and organizational values or culture (Boxx, Odom, \& Dunn, 1991). Previous studies explained various conceptualization of P-O fit, however the two most frequently used dimensions of P-O fit are goals and values (Piasentin and Chapman, 2006).

Research on P-O fit shows that a congruence between the focal person and the organization leads to many positive outcomes and they rely upon the concept of "supplementary" fit (Ostroff, Shin, \& Feinberg, 2002). The reason behind this positive relationship is that an employee desires to have a job that strengthens his self-concepts. Therefore, values matter a lot through which individual perceive situation and examine acceptable behavior, while achieving value congruence is the basic instrument for successful adaptation in the organization (Adkins, Ravlin and Meglino, 1996). The attraction-selection-attrition framework proposed that employees are concerned about other individuals in the particular organizations having relevant goals or they help in the accomplishment of their own goals (Schneider, 1987). So, obtaining goal congruence leads to motivational outcome (Locke, 1976) and positive affective outcomes (Edwards and Cable, 2009). These goals influencing individuals interest to align with organizational interests, thus working for common interest. Employees with high P-O fit are highly concern to align their day to day activities with those of the organization (Schein, 1992). Based on the above findings, it has been hypothesized that:

H3. : $P-O$ fit is significantly and positively related with job performance.

H4. : $P-O$ fit is positively and significantly related with job satisfaction.

\subsection{Job satisfaction as a mediator between $P-E$ fit and job performance}

Job satisfaction has been defined as "a positive or pleasurable reaction resulting from the appraisal of one's job, job achievement, or job experiences" (Locke, 1969, p.317). Similarly, Dawis and Lofquist (1984) defined job satisfaction as "a pleasurable affective condition resulting from one's appraisal of the way in which the experienced job situation meets one's needs, values, and expectations" (p.72). These definitions combined two separate characteristics of attitudes, the first characteristics focus on employee affective reaction towards the job, and the second described the evaluation of the employee desires from the job (Olson \& Zanna, 1993). As described previously, Locke (1969) suggested that job satisfaction is the outcome of the employee evaluation of the job values and these values, what employee actually want to attain.

P-E fit effects employees numerous outcomes positively (Verquer, Beehr, \& Wagner, 2003). These outcomes are categorized into three main areas, the first category is attitude (Dawis and Lofquist, 1984); the second category mental and physical (Edwards, Caplan, \& Harrison, 1998); and the third category includes job performance and contextual performance (Dawis and Lofquist, 1984). Hence this study focused on the first and third outcome of P-E fit. According to Goodhue and Thompson (1995), performance is the degree of an individual's ability to perform a specific task. As from the first definition of Edwards (1991), it has been observed that an individual knowledge, skills, and abilities congruent to their job are expected to a successful performer and will produce positive work outcomes.

Researchers on organizational psychology described that a job which the employee is attached, that provide him some values are considered to be satisfied. In contrast, when the job value does not match with the values of the employee, he will be dissatisfied from their job (Cable and Judge, 1997). A plethora of research supported significant positive relationship between job satisfaction and job performance. This common relationship is named as the "Holy Grail" by the industrial organizational psychologists (Weiss \& Cropanzano, 1996). The relationship between employee job satisfaction and job performance is higher and constant. Researchers also described that happy employees perform bitterly then unsatisfied employees (Judge, Erez, Bono, \& Thoresen, 2003; Ziegler, Hagen, \& Diehl, 2012). Therefore, based on the above findings it is hypothesized that:

H5. : Job satisfaction is positively associated with job performance.

H6. : P-J fit and job performance is positively mediated by job satisfaction.

H7. : P-O fit and job performance is positively mediated by the job satisfaction. 


\subsection{Power distance}

In the context of cross-national fit, the present study focused to answer the question that how culture moderates the relationship between P-E fit and job satisfaction. Prior studies found that relational fit are more influence on employee outcomes in East Asia then in North America whereas rational fit are more salient in North America (Oh et al., 2014). However there are limited research available in the aforementioned context on moderating role of culture, high power distance, is rather ambivalent. Further there is a huge difference between the levels of fit regarding the high qualification of teachers between the two countries. Thus we examined high power distance dimension empirically. Culture is a composite phenomenon. Anthropologists defined culture in more than hundred different ways (Kroeber \& Kluckhohn, 1952). A comprehensive definition is that of (Tylor,1958) who define culture as "that composite whole which includes knowledge, art, morals, law, belief, custom, and any other capabilities and habits acquired by man as a member of society" (p.1). Culture too effects on organizational performance. The attitudinal and behavioral outcomes of the employee's vary from culture to culture based on the values the employee's have at workplace (Odom, Boxx, \& Dunn, 1990). In a culture where power distance is low the organizations are less hierarchical, the employees are given free choice, and they have more autonomy as compared to high power distance culture, and they are pleased when their preferences are fulfilled from the organization (Lee \& Antonakis, 2012). Peterson et al. (1995) found that employees in high power distance culture are "context-sensitive" and they are found as more loyal to authority, also they are not too much jealous about value choices. P-O fit should be more correlated with organization specific outcomes e.g., turnover intentions and organizational outcomes. Based on the above findings, culture moderate the relationship between P-E fit and job satisfaction, thus it is hypothesized that.

H8. : P-J fit and job satisfaction is significantly moderated by the power distance.

H9. : P-O fit and job satisfaction is positively moderated by the power distance.

\subsection{Theoretical framework}

The theoretical relationship between P-J fit, P-O fit, power distance, job satisfaction, and job performance is represented in Fig. 1.

\section{Methodology}

\subsection{Population and sample}

The population of the present study is the faculty members in Afghanistan (Kabul) and Pakistan (Islamabad). At the time of data collection there are forty two universities thirty eight are from private sector and four of them are from public universities in Kabul whereas in Islamabad a total of fourteen universities with their head offices, out of which ten from public sector and four from private sector universities. The total populations of the faculty members are unknown as there are no official data available regarding the numbers of faculty members. Beside that the existing of different kind of faculty members like permanent, visiting, internees and contract faculties in every universities made the exact population difficult. So, a non-probability sampling technique, a convenient sampling, is used to collect the data.

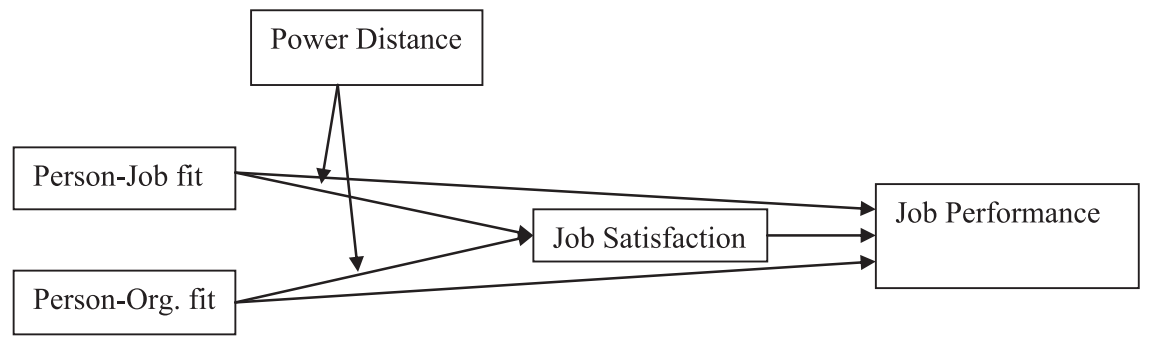

Fig. 1. Theoretical framework. 
The target sample of this study is faculty members, teaching in universities because of the ease the data collection from the university teachers in both sample and the lack of fit regarding their position. In a cross-national study, it is necessary to create sample size that is comparable (Sekaran, 1983). In Kabul, initially 235 questionnaires are circulated and 180 useful feedbacks are received. The response rate is 67\%. In Islamabad, 320 questionnaires are circulated and 270 are received back. The response rate is $84 \%$.

\subsection{Instrumentations}

The questionnaires for P-J fit are adopted from Lauver and Kristof-Brown (2001). These are five items. A three item scale is adopted from Cable and Judge (1996) to measure P-O fit. The moderating variable, power distance is measured through six items scale developed by Dorfman and Howell (1988). Job satisfaction is measured using a three items scale developed by Tsui, Pearce, Porter and Tripoli (1997). Supervisor (Head of the Department/Dean) rated job performance scale is adopted from Williams and Anderson (1991). The scale includes seven items. The sample items consist of "Adequately completes assigned duties' and 'fulfills responsibilities specified in the job description". All the responses from the participants are achieved on a five point Likert scale ranging from "strongly disagree" (1) to "strongly disagree" (5).

\subsection{Reliability analysis of scales}

To identify the inner problems in the questionnaire as well as the standard practice in survey research (Groves, 2004). A pilot study is conducted to assess the reliability of the scales used in this study and to find out deficiencies that may occur to disturb the original data. The instruments used in the survey shows satisfactory coefficient alpha more then (0.7) for all the items. In addition the Table 1 represents the reliability analysis of the scales used in this study. The reliability of the scales is examined using Chronbach's alpha. It is the degree of internal consistency and reliability. The coefficient alpha value must exceed the minimum standard of 0.70 levels to provide good estimates and to retain the items (Nunnally, 1994). The results of reliability analysis reveal that the value of Chronbach's alpha for all scales is greater than 0.7 , which reveals that the scales are reliable for analysis.

\section{Empirical results}

\subsection{Descriptive statistics}

Descriptive statistics is carried out to examine the essence of responses. The results for Kabul and Islamabad are reported in Table 2. As the participants were asked to respond on a five-point Likert scale ranging from "strongly disagree" (1) to "strongly disagree" (5). The descriptive statistics of Kabul showed that mean values of P-J fit and P-O fit are 4.5111 and 4.4315 respectively, which shows that most of the respondents agreed with existence of P-E fit in their organizations. The mean value of power distance is 1.48 , which shows that respondents disagreed with existence of power distance in an educational sector of Kabul. The mean values of job satisfaction and job performance are 4.5037 and 4.4384 respectively, which shows that respondents are agreed with existence of job satisfaction and job performance in an educational sector of Kabul. The data of P-J fit, P-O fit is positively skewed, while data of power distance, job satisfaction and job performance is negatively skewed. The common rule of thumb for normal distribution values for kurtosis is ranging from -2 and +2 (Landau and Everitt, 2004), while the skewness value more

Table 1

Reliability analysis of Kabul and Islamabad.

\begin{tabular}{llll}
\hline Variable & Items & Kabul Islamabad \\
\hline Person Job Fit & 5 & 0.796 & 0.800 \\
Person Organization Fit & 3 & 0.747 & 0.760 \\
Power Distance & 6 & 0.833 & 0.833 \\
Job Satisfaction & 3 & 0.898 & 0.901 \\
Job Performance & 21 & 0.868 & 0.867 \\
\hline
\end{tabular}


Table 2

Descriptive statistics.

\begin{tabular}{|c|c|c|c|c|c|}
\hline Variables & $\mathrm{N}$ & Mean & $\begin{array}{l}\text { Std. } \\
\text { Deviation }\end{array}$ & Skewness & Kurtosis \\
\hline \multicolumn{6}{|l|}{ Kabul } \\
\hline Person-job fit & 180 & 4.5111 & .38183 & 0.075 & -1.408 \\
\hline Person- & 180 & 4.4315 & .43110 & 0.016 & -1.376 \\
\hline \multicolumn{6}{|l|}{ Organization fit } \\
\hline Power distance & 180 & 1.4861 & .36738 & -0.013 & -1.322 \\
\hline Job Satisfaction & 180 & 4.5037 & .45326 & -0.098 & -1.821 \\
\hline Job performance & 180 & 4.4384 & .40147 & -0.121 & -0.850 \\
\hline \multicolumn{6}{|l|}{ Islamabad } \\
\hline Person-job fit & 270 & 4.4963 & .38201 & 0.143 & -1.405 \\
\hline Person- & 270 & 4.4173 & .43155 & 0.081 & -1.399 \\
\hline \multicolumn{6}{|l|}{ Organization fit } \\
\hline Power distance & 270 & 1.4981 & .36653 & -0.075 & -1.311 \\
\hline Job Satisfaction & 270 & 4.4852 & .45398 & -0.021 & -1.831 \\
\hline Job performance & 270 & 4.4226 & .39641 & -0.028 & -0.860 \\
\hline
\end{tabular}

than twice of its standard error show a departure from the symmetry. So, in our case the Kurtosis value in Kabul as shown in Table (2) are at the range of -1.408 to - 0.850. In case of Islamabad as shown in Table (2), the Kurtosis value range from -1.405 to -.860 . The skewness values are not more than twice of its standard error in both the table.

The descriptive statistics of Islamabad showed that all the variables are found significantly in the studied area. The mean values of P-J fit and P-O fit in Islamabad are 4.4963 and 4.4173 respectively, which shows that respondents are agree with existence of P-E fit in this organization. The mean value of power distance is 1.4981, which shows that the respondents are disagree with existence of power distance in an educational sector of Islamabad. The mean values of job satisfaction and job performance are 4.4852 and 4.4226, which shows that respondents are disagree with existence of job satisfaction and job performance.

\subsection{Correlation analysis}

The results of correlation among the variables in samples of both Kabul and Islamabad are reported in Table 3. The correlation results for Kabul indicates that P-J fit is positively correlated with $\mathrm{P}-\mathrm{O}$ fit $\left(\mathrm{r}=0.723^{* *}, \mathrm{p}<0.01\right)$ and negatively correlated with power distance $\left(\mathrm{r}=-0.681^{* *}, \mathrm{p}<0.01\right)$. Moreover, $\mathrm{P}-\mathrm{O}$ fit is negatively associated with power distance $\left(\mathrm{r}=-0.644^{* *}, \mathrm{p}<0.01\right)$. Power distance is negative related with job satisfaction $\left(\mathrm{r}=-0.440^{* *}\right.$,

Table 3

Correlation analysis.

\begin{tabular}{|c|c|c|c|c|c|}
\hline Variables & 1 & 2 & 3 & 4 & 5 \\
\hline \multicolumn{6}{|l|}{ Kabul } \\
\hline 1.Person-job fit & 1 & & & & \\
\hline 2. Person-Organization fit & $.723 * *$ & 1 & & & \\
\hline 3.Power distance & $-.681 * *$ & $-.644 * *$ & 1 & & \\
\hline 4.Job Satisfaction & $.514 * *$ & $.732 * *$ & $-.440 * *$ & 1 & \\
\hline 5.Job performance & $.474 * *$ & $.523 * *$ & $-.458 * *$ & $.671^{* *}$ & 1 \\
\hline \multicolumn{6}{|l|}{ Islamabad } \\
\hline 1.Person-job fit & 1 & & & & \\
\hline 2.Person-Organization fit & $.733 * *$ & 1 & & & \\
\hline 3.Power distance & $-.680 * *$ & $-.652 * *$ & 1 & & \\
\hline 4.Job Satisfaction & $.540 * *$ & $.708 * *$ & $-.464 * *$ & 1 & \\
\hline 5.Job performance & $.483 * *$ & $.528 * *$ & $-.467 * *$ & $.670 * *$ & 1 \\
\hline
\end{tabular}

Note: $* *$ indicates $p<.01$. 
$\mathrm{p}<0.01)$ and with job performance $\left(\mathrm{r}=-0.458^{* *}, \mathrm{p}<0.01\right)$. But contrary to expectations the values showed negative relationships with power distance. These results are consistent with previous findings that some kinds of fit (rational) are more preferable in western cultures while others kinds of fit like, relational, are more stronger in East Asia (Oh et al., 2014). In addition, Hofstede (1980) dimensions have also some limitations which he equated nation states with culture so the possible negative association may be due to unclear theorizing of culture at all (Baskerville, 2003). Job satisfaction is positively correlated with P-J fit $\left(\mathrm{r}=0.514^{* *}, \mathrm{p}<0.01\right)$, P-O fit $(\mathrm{r}=0.732 * *, \mathrm{p}<0.01)$, and with job performance $\left(\mathrm{r}=0.671^{* *}, \mathrm{p}<0.01\right)$. Job performance is positively correlated with P-J fit $\left(\mathrm{r}=0.474^{* *}\right.$, $\mathrm{p}<0.01)$ and P-O fit $\left(\mathrm{r}=0.523^{* *}, \mathrm{p}<0.01\right)$. These results are consistent with findings of Kim, Aryee, Loi \& Kim (2013), Lee and Antonakis (2012), Chuang, Hsu, Wang, \& Judge (2015).

Table 4

Main effect, moderated \& mediated regression analysis of PJF, PD, JS \& JP of Kabul.

\begin{tabular}{|c|c|c|c|c|c|c|}
\hline \multirow[t]{2}{*}{ Predictors } & \multicolumn{3}{|c|}{ Mediator JS } & \multicolumn{3}{|c|}{ Dependent JP } \\
\hline & $\beta$ & $R^{2}$ & $\Delta R^{2}$ & $\beta$ & $R^{2}$ & $\Delta R^{2}$ \\
\hline \multicolumn{7}{|c|}{ Main effect: PJF } \\
\hline \multicolumn{7}{|l|}{ Step1 } \\
\hline $\begin{array}{l}\text { Control } \\
\text { variables }\end{array}$ & & 0.081 & & & 0.077 & \\
\hline \multicolumn{7}{|l|}{ Step 2} \\
\hline PJF & $0.582 * * *$ & 0.313 & 0.232 & $0.476 * * *$ & 0.275 & 0.198 \\
\hline \multicolumn{7}{|c|}{ Moderator Analysis PD } \\
\hline \multicolumn{7}{|l|}{ Step 1} \\
\hline $\begin{array}{l}\text { Control } \\
\text { variables }\end{array}$ & & 0.081 & & & & \\
\hline \multicolumn{7}{|l|}{ Step 2} \\
\hline PJF & $2.363 * * *$ & 0.395 & 0.314 & & & \\
\hline $\mathrm{PD}$ & $1.875 * * *$ & & & & & \\
\hline \multicolumn{7}{|l|}{ Step 3} \\
\hline $\mathrm{PJF} \times \mathrm{PD}$ & $0.021 \mathrm{~ns}$ & 0.397 & 0.002 & & & \\
\hline
\end{tabular}

Mediation JS

Step1

Control

0.077

variables

Step 2

JS

$0.589^{* * * *}$

0.483

0.407

Step 3

PJF

$0.178^{*}$

0.504

0.021

Notes: age, gender, education, experience and marital status were control variables. PJF is person-job fit, PD is power distance, JS is job satisfaction, JP is job performance.

$\mathrm{n}=180 . * * * * * * *$ indicates $\mathrm{p}<0.001,0.01,0.05$ respectively. 
In case of Islamabad, the results of correlation shows that P-J fit is positively related with P-O fit $(\mathrm{r}=0.733 * *$, $\mathrm{p}<0.01)$ and negatively related with power distance $\left(\mathrm{r}=-0.680^{* *}, \mathrm{p}<0.01\right)$. The P-O fit is negatively related with power distance $(\mathrm{r}=-0.652 * *, \mathrm{p}<0.01)$. Power distance is negatively correlated with job satisfaction $(\mathrm{r}=-0.464 * *$, $\mathrm{p}<0.01)$ and job performance $\left(\mathrm{r}=-0.467^{* *}, \mathrm{p}<0.01\right)$. Although the findings are somehow surprising but from numerous other findings it is consistent that high power distance may not be positively associated with employee attitude and behavioural outcomes. Job satisfaction is positively correlated with P-J fit $\left(\mathrm{r}=0.540^{* *}, \mathrm{p}<0.01\right)$, P-O fit $\left(\mathrm{r}=0.708^{* *}, \mathrm{p}<0.01\right)$, and job performance $\left(\mathrm{r}=0.670^{* *}, \mathrm{p}<0.01\right)$. Furthermore, job performance is positively

Table 5

Main effect, moderated \& mediated regression analysis of POF, PD, JS \& JP of Kabul.

\begin{tabular}{|c|c|c|c|c|c|c|}
\hline \multirow[t]{2}{*}{ Predictors } & \multicolumn{3}{|c|}{ Mediator JS } & \multicolumn{3}{|c|}{ Dependent JP } \\
\hline & $\beta$ & $R^{2}$ & $\Delta R^{2}$ & $\beta$ & $R^{2}$ & $\Delta R^{2}$ \\
\hline \multicolumn{7}{|l|}{$\begin{array}{l}\text { Main effect: } \\
\text { POF }\end{array}$} \\
\hline $\begin{array}{l}\text { Step1 } \\
\text { Control } \\
\text { variables }\end{array}$ & & 0.081 & & & 0.077 & \\
\hline Step 2 & & & & & & \\
\hline Moderation PD & $0.793 * * *$ & 0.601 & 0.520 & $0.488 * * *$ & 0.327 & 0.250 \\
\hline $\begin{array}{l}\text { Step } 1 \\
\text { Control } \\
\text { variables }\end{array}$ & & 0.081 & & & & \\
\hline $\begin{array}{l}\text { Step2 } \\
\text { POF } \\
\text { PD }\end{array}$ & $\begin{array}{l}0.852 * * * \\
0.103 * * *\end{array}$ & 0.605 & 0.524 & & & \\
\hline $\begin{array}{l}\text { Step } 3 \\
\quad \text { POF } \times \text { PD }\end{array}$ & $-0.410 \mathrm{~ns}$ & 0.620 & 0.016 & & & \\
\hline
\end{tabular}

Mediation JS

Step1

Control

0.077

variables

Step 2

JS

$0.589 * * *$

0.483

0.407

Step 3

POF

$0.047 \mathrm{~ns}$

0.484

0.001

Notes: age, gender, education, experience and marital status are control variables. POF is person-organization fit, PD is power distance, JS is job satisfaction, JP is job performance.

$\mathrm{n}=180 . * * *, * * * *$ indicates $\mathrm{p}<0.001,0.01,0.05$ respectively. 
related with P-J fit $\left(\mathrm{r}=0.483^{* *}, \mathrm{p}<0.01\right)$ and P-O fit $\left(\mathrm{r}=0.528^{* *}, \mathrm{p}<0.01\right)$. Similarly, these positive relationships are supported from the meta-analysis of (Krist of-Brown et al., 2005; Oh et al., 2014).

\subsection{Regression analysis}

To examine the moderating effect of power distance and mediating effect of job satisfaction between P-J fit and P-O fit and employee job performance we followed Baron and Kenny's (1986) method for rest of the results. Results shown in Table 4 show the direct and indirect relationship P-J fit, power distance, job satisfaction, and job performance of Afghanistan (Kabul). The results indicated that P-J fit significant positively affects job performance ( $\beta$

Table 6

Main effect, moderated \& mediated regression analysis of PJF, PD, JS \& JP of Islamabad.

\begin{tabular}{|c|c|c|c|c|c|c|}
\hline \multirow[t]{2}{*}{ Predictors } & \multicolumn{3}{|c|}{ Mediator JS } & \multicolumn{3}{|c|}{ Dependent JP } \\
\hline & $\beta$ & $R^{2}$ & $\Delta R^{2}$ & $\beta$ & $R^{2}$ & $\Delta R^{2}$ \\
\hline \multicolumn{7}{|c|}{ Main effect: PJF } \\
\hline \multicolumn{7}{|l|}{ Step1 } \\
\hline $\begin{array}{l}\text { Control } \\
\text { variables }\end{array}$ & & 0.045 & & & 0.022 & \\
\hline \multicolumn{7}{|l|}{ Step 2} \\
\hline PJF & $0.633^{* * * *}$ & 0.327 & 0.282 & $0.504 * * *$ & 0.256 & 0.235 \\
\hline
\end{tabular}

Moderation PD

\begin{tabular}{|c|c|c|}
\hline $\begin{array}{c}\text { Step } 1 \\
\text { Control } \\
\text { variables }\end{array}$ & & 0.045 \\
\hline Step2 & & \\
\hline PJF & $2.214 * * *$ & \\
\hline PD & $1.997 * * *$ & 0.424 \\
\hline Step 3 & & \\
\hline $\mathrm{PJF} \times \mathrm{PD}$ & $0.055 \mathrm{~ns}$ & 0.425 \\
\hline
\end{tabular}

Mediation JS

Step1

Control

variables

Step 2

JS

$0.589 * * *$

0.471

0.407

Step 3

PJF

$0.032 \mathrm{~ns}$

0.492

0.020

Notes: age, gender, education, experience and marital status are control variables. PJF is person-job fit, PD is power distance, JS is job satisfaction, JP is job performance.

$\mathrm{n}=270 . * * * * * * *$ indicates $\mathrm{p}<0.001,0.01,0.05$ respectively. 
$=0.476, \mathrm{p}<.001$ ) which supports Hypothesis 1 . The second step showed the significant positive relationship between P-J fit and job satisfaction $(\beta=0.582, \mathrm{p}<.001)$ supporting hypothesis 3 . In addition, the results indicated significant positive relationship between job satisfaction $\&$ job performance $(\beta=0.589, \mathrm{p}<.001)$ which supports hypothesis 5. After controlling the mediating variable effects of P-J fit become significant when role of job satisfaction take in consideration $(\beta=0.178, \mathrm{p}<0.05)$. It shows that job satisfaction partially mediates the relationship between P-J fit and job performance, which partially supports hypothesis 8 . Prior research supports this particular relationship between P-J fit with job satisfaction and job performance (Judge et al., 2003; Harrison et al., 2006). Moreover, one of the notable findings of this study indicated that power distance doesn't moderate the relationship between P-J fit and job satisfaction because the interaction term of P-J fit and power distance is insignificant $(\beta=0.021 \mathrm{~ns})$ and the value of change in $\mathrm{R}$ square is low $\left(\Delta \mathrm{R}^{2}=0.002\right)$.

Table 5 reports the regression results of moderation and mediation analysis of P-O fit, power distance, job satisfaction, and job performance of Kabul. Hypothesis 2, proposed that P-O fit positively affect job performance ( $\beta$

Table 7

Main effect moderated \& mediated regression analysis of POF, PD, JS \& JP of Islamabad.

\begin{tabular}{|c|c|c|c|c|c|c|}
\hline \multirow[t]{2}{*}{ Predictors } & \multicolumn{3}{|c|}{ Mediator JS } & \multicolumn{3}{|c|}{ Dependent JP } \\
\hline & $\beta$ & $R^{2}$ & $\Delta R^{2}$ & $\beta$ & $R^{2}$ & $\Delta R^{2}$ \\
\hline \multicolumn{7}{|l|}{ Main effect: POF } \\
\hline \multicolumn{7}{|l|}{ Step1 } \\
\hline Control variables & & 0.045 & & & 0.022 & \\
\hline \multicolumn{7}{|l|}{ Step 2} \\
\hline POF & $0.819^{* * *}$ & 0.618 & 0.574 & $0.502^{* * * *}$ & 0.304 & 0.282 \\
\hline \multicolumn{7}{|l|}{ Moderation PD } \\
\hline \multicolumn{7}{|l|}{ Step 1} \\
\hline \multicolumn{7}{|l|}{ Control variables } \\
\hline \multicolumn{7}{|l|}{ Step 2} \\
\hline POF & $0.881^{* * * *}$ & & & & & \\
\hline $\mathrm{PD}$ & $0.105^{*}$ & 0.622 & 0.578 & & & \\
\hline \multicolumn{7}{|l|}{ Step 3} \\
\hline $\mathrm{POF} \times \mathrm{PD}$ & $-0.385 \mathrm{~ns}$ & 0.635 & 0.013 & & & \\
\hline
\end{tabular}

Mediation JS

Step1

Control variable

0.022

Step 2

JS

$0.589^{\text {**** }}$

0.471

0.450

Step 3

POF

$0.028 \mathrm{~ns}$

0.472

0.001

Notes: age, gender, education, experience and marital status are control variables. POF is person-organization fit, PD is power distance, JS is job satisfaction, JP is job performance.

$\mathrm{n}=180 . * * *, * * *$ indicates $\mathrm{p}<0.001,0.01,0.05$ respectively. 
$=0.488, \mathrm{p}<.001)$. The second step indicated significant positive relationship between P-O fit and job satisfaction $(\beta$ $=0.793, \mathrm{p}<.001$ ) which supports hypothesis 2 and 4 . In addition, the results also indicated significant relationship between job satisfaction and job performance $(\beta=0.589, \mathrm{p}<.001)$ supporting hypothesis 5 . After controlling the mediating effects of $\mathrm{P}-\mathrm{O}$ fit become insignificant when the role of job satisfaction taken into consideration $(\beta=$ $0.047 \mathrm{~ns})$. It shows that job satisfaction mediates the relationship between person-organization fit and job performance, which supports Hypothesis 9. Past research supports this particular relationships (Fisher, 2003; Ziegler et al. 2012; Kristof-Brown \& Guay, 2010). In reference to Kabul, the findings indicated that power distance doesn't moderate the relationship between P-O fit and job satisfaction because the interaction term of P-J fit and power distance is insignificant $(\beta=-0.385 \mathrm{~ns})$ and the value of change in $\mathrm{R}$ square is low $\left(\Delta \mathrm{R}^{2}=0.013\right)$.

Similarly in the sample of Pakistan (Islamabad) for regression analysis we followed Baron and Kenny's (1986) procedures for examining the moderating effect of power distance and mediating effect of job satisfaction between P-J fit and P-O fit and employee job performance. Table 6 reports the regression analysis of P-J fit, power distance, job satisfaction, and job performance of Islamabad. Hypothesis 1, in case of Islamabad suggested that P-J fit positively effects on employee job performance, the values $(\beta=0.504, \mathrm{p}<.001)$ supports hypothesis 1 . Similarly the results indicated that P-J fit have positive effects on job satisfaction $(\beta=0.633, p<.001)$ supporting hypothesis 3 . In addition, the results also indicated a significant positive relations between job satisfaction $\&$ job performance $(\beta=$ $0.589, \mathrm{p}<.001$ ) which supports Hypothesis 5.Similarly, this study found that job satisfaction significantly mediate the relationship between P-J fit and job performance. While controlling the mediating variable effects of P-J fit become insignificant when role of job satisfaction take in consideration $(\beta=0.032 \mathrm{~ns})$. It shows that job satisfaction mediates the relationship between P-J fit and job performance, which supports Hypothesis 8. Similar findings are found by previous studies of (Iplik et al. 2011, Cable \& DeRue, 2002).

We predicted in hypothesis 6 that, power distance moderates the relationship between P-J fit and job satisfaction. However, our findings suggests that power distance does not moderates the relationship, because the interaction term of the P-J fit and power distance is insignificant $(\beta=0.055 \mathrm{~ns})$ and the value of change in $\mathrm{R}$ square is low $\left(\Delta \mathrm{R}^{2}=\right.$ $0.001)$.

Table 7 reports the moderation and mediation analysis of $\mathrm{P}-\mathrm{O}$ fit, power distance, job satisfaction, and job performance of Islamabad. Hypothesis 1 stated that $\mathrm{P}-\mathrm{O}$ fit have positive impacts on job performance $(\beta=0.502$, $\mathrm{p}<.001$ ) so supports hypothesis 2 . Furthermore the results showed the significant positive relationship between P-O fit and job satisfaction $(\beta=0.819, \mathrm{p}<.001)$ which supports hypothesis 4 . The results indicated a significant relationship between job satisfaction $\&$ job performance $(\beta=0.589, \mathrm{p}<.001)$ which supports hypothesis 5 . Later on by controlling the mediating effect the value is insignificant $(\beta=0.028 \mathrm{~ns})$. It shows that job satisfaction mediates on the relationship between P-O fit and job performance, supporting hypothesis 9. Past literature supports these particular relationships (Kristof-Brown et al., 2005; Hoffman, Bynum, Piccolo, \& Sutton, 2011). However power distance doesn't moderate the relationship between P-O fit and job satisfaction, the interaction term of P-J fit and power distance is insignificant $(\beta=-0.385 \mathrm{~ns})$ and the value of change in $\mathrm{R}$ square is low $\left(\Delta \mathrm{R}^{2}=0.013\right)$. This unpredictable relationship is explained in detail in the discussion part of this study.

\subsection{Discussion of results}

The present study proposed and test a moderated and mediated model linking P-E fit to employee job satisfaction and employee job performance in high power distance cultures. Job satisfaction has positively mediated the relationship between P-E fit and employee job performance. Contrary to expectations power distance does not moderate the relationship between P-E fit and job satisfaction in both samples.

Overall the results of this study are quite similar in reference to Kabul and Islamabad. The results indicated significant positive relationship between P-J fit and job performance in Kabul and similarly in Islamabad. This result is consistent with the findings of (Li \& Hung, 2010; Greguras \& Diefendorff, 2009; Oh et al., 2014). Similarly this study found significant positive relationship between P-O fit and job performance in both Kabul and Islamabad. This result corroborated with the findings of (Dawis \& Lofquist, 1984; Kristof, 1996). Furthermore, this study find significant positive relationship of P-J fit and P-O fit with job-satisfaction in Kabul and Islamabad. Similar positive relationships are found in various studies (Edwards, 1991; Greguras \& Diefendorff, 2009). In addition, the results indicated significant positive relationship between job satisfaction and job performance. This result is consistent with previous findings of (Ziegler et al. 2012). The findings are also consistent with two-factor theory of job satisfaction 
(Herzberg, Mausner, \& Snyderman, 1959) which is based on the proposition that performance is the outcome of employee job satisfaction.

This study found that job satisfaction significantly mediates the relationship between P-J fit and job performance, and between P-O fit and job performance. The results are similar in Kabul and Islamabad, however there is full mediation in case of Islamabad, while partial mediation in reference to Kabul. This may be the fact that in Islamabad the level of fit is high as compared to Kabul. So if employees have the right type of knowledge, skills and abilities that is required to perform his/her duty, this match or congruence of values results more effectively at their workplace. Thus their achievement will be high and the employee will perceive satisfaction. These findings are in line with previous findings of (Edwards, 2007; Kristof-Brown \& Guay, 2010). According to common sense theory Fisher (2003), "happy employees are productive individuals, or that employee's who are satisfied with their jobs are likely to be better performers on those jobs".

The moderation analysis highlighted some interesting results. The results highlighted that power distance doesn't moderate the relationship between P-J fit and job performance, and similarly between P-O fit and job performance in case of Kabul and Islamabad. These findings are inconsistent with previous findings of various studies ( $\mathrm{Ng}$, Sorensen, \& Yim 2009; Hofstede, 1980). However, there are some studies which suggest that P-E fit may not play an important role in a high power distance culture (Lee \& Antonakis, 2012). Moreover, people in a high power distance culture give more preference to what has been provided by their organization and supervisor. Employees in such cultures are well trained to be respect and obey what has been provided to them. In addition, historically in Afghanistan and Pakistan decision making has been very centralized and autocratic and employees are less empowered. The tolerance for high power distance has led to the culture of sycophancy throughout the administrative systems in Pakistan the employees consider it necessary for high promotions and fringe benefits (Mazari, 1999). This model is initially forced from the top and to some extent it is appreciated from below. As usual, managers in our context are punished and selfresponsible for negative outcomes even those unpredictable in the past. Since, Pakistan independence a strong executive system has been dedicated in all the constitutional institutions which led to high centralized organizational culture (Newberg, 1995). This tolerance for high power distance led to the culture of sycophancy throughout the administrative systems in Pakistan the employees consider it necessary for high promotions and fringe benefits (Mazari, 1999).

Another possible explanation as to why power distance does not effect as a moderator may be the fact that power distance is not a strong cultural dimension in Afghanistan and Pakistan. Hofstede (1980) classified countries in extreme level in his cultural index, the countries that scored below 50 is low power distance culture and above 50 he called it as high power distance culture. Although he expanded his cultural dimensions, another reason that why power distance does not moderate may be the time by considering South Asian countries as high power distance culture. Hence, the current study suggests that there should be a moderate level of power distance in future studies. Later on, Hofstede (1991), confirmed that although power distance are decreased worldwide, the difference between the countries should remain, "The countries have moved to lower power distance levels without changes in their mutual ranking" (p.46). All in all, employees in Afghanistan and Pakistan have high endurance to follow the instructions of the organization and supervisor then to their own needs and desires. So, employees in these cultures, feel happy if their personal preferences are consistent with organization cultural norm because cultural values are stronger then personal values.

\section{Conclusion}

This study investigated the relationship of P-E fit with job satisfaction, job performance in the high power distance cultures. The estimations are based on the capital of two countries Afghanistan and Pakistan, named Islamabad and Kabul. The result of the study showed significant positive relationship of P-J fit, P-O fit with job satisfaction and job performance. The result of the samples proved that P-J fit, P-O fit direct effect on job performance and also indirect through job satisfaction. In addition, job satisfaction mediated the relationship between P-J fit and job performance in Kabul and Islamabad. The notable findings indicated that power distance does not moderate the relationship between P-J fit and job satisfaction, and with P-O fit and job satisfaction in both the samples. The results of the study proved that greater level of fit between P-J and workplace leads to greater level of effectiveness for the organization. A possible explanation of these findings would be that an employee's (teachers) will not be able to perform well, until 
they are not equipped first with right type of knowledge skills and abilities and value congruence between person and the organization.

Although a plethora of research has studied P-E fit is an important organizational strategy for fostering, motivating and maintaining social exchange relationships. This study expanded the call for cross-cultural studies on P-E fit concepts by many authors (e.g., Schneider, 2001; Lee \& Antonakis, 2012). Another important contribution is the moderating role of power distance in novel context and how it effects on P-E fit and employee job satisfaction.

The empirical findings on fit supported that a higher level of fit leads to job satisfaction and job performance (Edwards, 1991). Top management of the organization should consider P-E fit as an important tool in order to have a competitive edge in the market while keeping in mind the role of culture in the organizational policies.

This study has some limitations and these limitations can be the future study as well. The first limitation is the selection of sample because that data is collected from the capitals only and the size of sample. Second, we have conducted the study in same culture, high power distance culture. It is highly recommended for future study to compare low and high power distance countries in order to generalize P-E fit theory. Third, as mentioned that we collected the data from the employees (teachers) regarding their P-J fit and P-O fit and also job performance. This can create common method bias or social desirability (Podsakoff, MacKenzie, Lee, \& Podsakoff, 2003). Fourth, we collected the data from the participants on a single time. Longitudinal studies are highly recommended for such a proposed model in other sectors as well. Fifth, we studied only one dimension of culture i.e. power distance, future study should include other cultural dimensions like, collectivism/individualism, uncertainty avoidance (Hofstede, 2001).

\section{References}

Adkins, C. L., Ravlin, E. C., \& Meglino, B. M. (1996). Value congruence between co-workers and its relationship to work outcomes. Group Organization Management, 21, 439-460.

Aris, N. M. (2007). SMEs: Building blocks for economic growth1. Journal of the Department of Statistics Malaysia, 1, 1-14.

Aycan, Z., Kanungo, R., Mendonca, M., Yu, K., Deller, J., Stahl, G., \& Kurshid, A. (2000). Impact of culture on human resource management practices: A 10-country comparison. Applied Psychology: An International Review, 49(1), 192-221.

Baron, R. M., \& Kenny, D. A. (1986). The moderator-mediator variable distinction in social psychological research: Conceptual, strategic, and statistical considerations. Journal of Personality and Social Psychology, 51(6), 1173-1182.

Bartram, D. (2005). The great eight competencies: A criterion-centric approach to validation. Journal of Applied Psychology, 90(6), 1185-1203.

Baskerville, Rachel F. (2003). Hofstede never studied culture. Accounting, Organizations and Society, 28(1), 1-14. (2003).

Bednarska, M. A. (2017). Does the effect of P-E fit on work attitudes vary with generations? insights from the tourism industry. International Journal of Management and Economics, 53(1), 65-83.

Boxx, W. R., Odom, R. Y., \& Dunn, M. G. (1991). Organizational values and value congruency and their impact on satisfaction, commitment, and cohesion: An empirical examination within the public sector. Public Personnel Management, 20(1), 195-205.

Cable, D. M., \& Judge, T. A. (1996). Person-organization fit, job choice decisions, and organizational entry. Organizational Behavior and Human Decision Processes, 67(3), 294-311.

Cable, D. M., \& Judge, T. A. (1997). Interviewers' perceptions of person-organization fit and organizational selection decisions. Journal of Applied Psychology, 82(4), 546-561.

Carless, S. A. (2005). Person-job fit versus person-organization fit as predictors of organizational attraction and job acceptance intentions: A longitudinal study. Journal of Occupational and Organizational Psychology, 78(3), 411-429.

Cable, D. M., \& DeRue, D. S. (2002). The convergent and discriminant validity of subjective fit perceptions. Journal of Applied Psychology, 87, $875-884$

Chuang, A., Hsu, R. S., Wang, A. C., \& Judge, T. A. (2015). Does west "fit" with east? In search of a Chinese model of person-environment fit. Academy of Management Journal, 58(2), 480-510.

D'Amato, A., \& Zijlstra, F. R. (2008). Psychological climate and individual factors as antecedents of work outcomes. European Journal of Work and Organizational Psychology, 17, 33-54.

Dawis, R. V., \& Lofquist, L. H. (1984). A psychological theory of work adjustment: An individual-differences model and its applications. Minneapolis, MN: University of Minnesota Press.

Dorfman, P. W., \& Howell, J. P. (1988). Dimensions of national culture and effective leadership patterns: Hofstede revisited. Advances in International Comparative Management, 3, 127-150.

Edwards, R. J. (1991). P-J fit: A conceptual integration, literature review, and methodological critique. International Review of Industrial/ Organizational Psychology, 6, 283-357.

Edwards, J. R., \& Cable, D. M. (2009). The value of value congruence. Journal of Applied Psychology, 94(3), 654-677.

Edwards, J. R., \& Shipp, A. J. (2007). The relationship between P-E fit and outcomes: An integrative theoretical framework. In: C. Ostroff, \& T. A. Judge (Eds.), Perspectives on organizational fit, 4 (pp. 58-209). San Francisco, CA: Jossey-Bass.

Edwards, J. R., Caplan, R. D., \& Harrison, R. V. (1998). P-E fit theory: Conceptual foundations, empirical evidence, and directions for future research. In: C. L. Cooper (Ed.), Theories of organizational stress (pp. 28-67). Oxford: Oxford University Press. 
Fisher, C.B. (2003). A goodness-of-fit ethic for child assent to non beneficial research.

Goodhue, D. L., \& Thompson, R. L. (1995). Task-technology fit and individual performance. MIS quarterly, 15, 213-236.

Greguras, G. J., \& Diefendorff, J. M. (2009). Different fits satisfy different needs: Linking P-E fit to employee commitment and performance using self-determination theory. Journal of Applied Psychology, 94(2), 465-487.

Groves, R. M. (2004). Survey errors and survey costs, 536. John Wiley \& Sons.

Hoffman, B. J., Bynum, B. H., Piccolo, R. F., \& Sutton, A.,W. (2011). Person-organization value congruence: How transformational leaders influence group effectiveness. Academy of Management Journal, 54, 779-796.

Herzberg, F., Mausner, B., \& Snyderman, B. (1959). The motivation to work. New York: Willey.

Hofstede, G. (1980). Culture's consequences: International differences in work related values. Beverly Hills, CA: Sage.

Hofstede, G. (1991). Cultures and organizations: Software of the mind. London: McGraw-Hill.

Hofstede, G. (2001). Culture's recent consequences: Using dimension scores in theory and research. International Journal of Cross Cultural Management, 1(1), 11-17.

Hofstede, G., \& Hofstede, G. J. (2005). Cultures and organizations: Software of the mind. New York, NY: McGraw-Hill.

Iplik, F. N., Kilic, K. C., \& Yalcin, A. (2011). The simultaneous effects of person-organization and P-J fit on Turkish hotel managers. International Journal of Contemporary Hospitality Management, 23(5), 644-661.

Judge, T. A., Erez, A., Bono, J. E., \& Thoresen, C. J. (2003). The core self-evaluations scale: Development of a measure. Personnel Psychology, 56 (2), 303-331.

Kim, T. Y., Aryee, S., Loi, R., \& Kim, S. P. (2013). Person-organization fit and employee outcomes: Test of a social exchange model. The International Journal of Human Resource Management, 24(19), 3719-3737.

Kristof, A. L. (1996). Person-organization fit: An integrative review of its conceptualizations, measurement, and implications. Personnel psychology, 49, 1.

Kristof-brown, a 1 (2000). Perceived applicant fit: Distinguishing between recruiters' perceptions of person-job and person-organization fit. Personnel Psychology, 53(3), 643-671.

Kristof-Brown, A. L., \& Guay, R. P. (2010). P-E fit. In: S. Zedeck (Ed.), APA handbook of industrial and organizational psychology. Washington, DC: APA.

Kristof-Brown, A. L., Jansen, K. J., \& Colbert, A. E. (2002). A policy-capturing study of the simultaneous effects of fit with jobs, groups, and organizations. Journal of Applied Psychology, 87(5), 985-993.

Kristof-Brown, A. L., Zimmerman, R. D., \& Johnson, E. C. (2005). Consequences of individual's fit at work: A meta-analysis of person-job, person-organization, person-group, and person-supervisor fit. Personnel Psychology, 58(2), 281-342.

Kroeber, A. L., \& Kluckhohn, C. (1952). Culture: A critical review of concepts and definitions. Harvard University. Papers. Peabody Museum of Archaeology \& Ethnology.

Landau, S., \& Everitt, B. (2004). A handbook of statistical analyses using SPSS, 1. Boca Raton, FL: Chapman \& Hall/CRC.

Lauver, K. J., \& Kristof-Brown, A. (2001). Distinguishing between employees' perceptions of person-job and person-organization fit. Journal of Vocational Behavior, 59(3), 454-470.

Lee, Y. t, \& Ramaswami, A. (2013). Fitting P-E fit theories into a national natural context. In: A. L. Kristof-Brown, \& J. Billsberry (Eds.), Organizational fit: Key issues and new directions (pp. 222-240).

Lee, Y. T., \& Antonakis, J. (2012). When preference if is not satisfied but the individual is: How power distance moderates person-job fit. Journal of Management (X(XX).

Lehman, D. R., Chiu, C. Y., \& Schaller, M. (2004). Psychology and culture. Annual Review of Psychology, 55, 689-714.

Lewin, K. (1935). Dynamic theory of personality. New York: McGraw-Hill.

Li, C. K., \& Hung, C. H. (2010). An examination of the mediating role of P-J fit in relations between information literacy and work outcomes. Journal of Workplace Learning, 22(5), 306-318.

Locke, E. A. (1969). What is job satisfaction?. Organizational Behavior and Human Performance, 4(4), 309-336.

Locke, E. A. (1976). The nature and causes of job satisfaction. In: M. D. Dunnette (Ed.), Handbook of industrial and organizational psychology (pp. 1297-1349).

Mazari, S. K. (Ed.) (1999). A journey to disillusionment. Oxford University Press, USA. Ministry of Higher Education, Human resources development, program 3. Annual report, 2013.

Mulky, A. G. (2012). An exploration of sales P-J satisfaction in india using pe fit constructs. Review of Business Research, 12(5).

Newberg, R., P. (1995). Judging the state (p. 4)Cambridge: Cambridge University Press4.

Ng, T. W., Sorensen, K. L., \& Yim, F. H. (2009). Does the job satisfaction-job performance relationship vary across cultures. Journal of CrossCultural Psychology, 40(5), 761-796.

Nolan, E. M., \& Morley, M. J. (2013). A test of the relationship between person-environment fit and cross-cultural adjustment among self-initiated expatriates. The International Journal of Human Resource Management, 25(11), 1631-1649.

Nunnally, J. C. (1994). Bernstein. IH (1994). Psychometric Theory, 3.

Nye, D., Su, R., Rounds, J., \& Drasgow, F. (2012). Vocational interests and performances: A quantitative summary of over 60 years of research. Perspectives on Psychological Science, 7(4), 384-403.

Odom, R. Y., Boxx, W. R., \& Dunn, M. G. (1990). Organizational cultures, commitment, satisfaction, and cohesion. Public Productivity Management Review, 14(2), 157-169.

Oh, I. S., Guay, R. P., Kim, K., Harold, C. M., Lee, J. H., Heo, C. G., \& Shin, K. H. (2014). Fit happens globally: A meta-analytic comparison of the relationships of person-environment fit dimensions with work attitudes and performance across East Asia, Europe, and North America. Personnel Psychology, 67(1), 99-152.

Olson, J. M., \& Zanna, M. P. (1993). Attitudes and attitude change. Annual Review of Psychology, 44, 117-154. 
Ostroff, C. (1992). The relationship between satisfaction, attitudes, and performance: An organizational level analysis. Journal of Applied Psychology, 77, 963-974.

Ostroff, C., Shin, Y., \& Feinberg, B. (2002). Skill acquisition and P-E fit. In: D. C. Feldman (Ed.), Work careers: A developmental perspective (pp. 63-90). San Francisco: Jossey-Bass.

Ostroff, C., Shin, Y., \& Kinicki, A. J. (2005). Multiple perspectives of congruence: Relationships between value congruence and employee attitudes. Journal of Organizational Behavior, 26(6), 591-623.

Peterson, M. F., Smith, P. B. Role conflict, ambiguity, and overload: A 21-nation study. Academy of Management Journal, 38, 429-452.

Piasentin, K. A., \& Chapman, D. S. (2006). Subjective person-organization fit: Bridging the gap between conceptualization and measurement. Journal of Vocational Behavior, 69, 202-221.

Podsakoff, P. M., MacKenzie, S. B., Lee, J. Y., \& Podsakoff, N. P. (2003). Common method biases in behavioral research: A critical review of the literature and recommended remedies. Journal of Applied Psychology, 88(5), 879-903.

Saks, A. M., \& Ashforth, B. E. (1997). A longitudinal investigation of the relationships between job information sources, applicant perceptions of fit, and work outcomes. Personnel Psychology, 50(2), 395-426.

Schein, E. H. (1992). Organizational culture and leadership. San Francisco: Jossey-Bass.

Schneider, B. (1987). The people make the place. Personnel Psychology, 40(3), 437-453.

Schneider, B. (2001). Fits about fit. Applied Psychology: An International Review, 50(1), 141-152.

Sekaran, U. (1983). Methodological and theoretical issues and advancements in cross-cultural research. Journal of International Business Studies, 14(2), 61-73.

Sonnentag, S., \& Frese, M. (2002). Performance concepts and performance theory. Psychological Management of Individual Performance, 23, $3-25$.

Swanson, P. B. (2012). The congruence of vocational interests and the workplace environment: Reducing the language teacher shortage. Language Teaching Research, 16, 519-537.

Triandis, H. C. (1994). Culture and social behavior. McGraw-Hill.

Tsui, A. S., Pearce, J. L., Porter, L. W., \& Tripoli, A. M. (1997). Alternative approaches to the employee-organization relationship: Does investment in employees pay off?. Academy of Management Journal, 40(5), 1089-1121.

Tylor, E. B. (1958). Primitive culture. New York, NY: Harper.

Verquer, M. L., Beehr, T. A., \& Wagner, S. H. (2003). A meta-analysis of relations between person-organization fit and work attitudes. Journal of Vocational Behavior, 63, 473-489.

Williams, L. J., \& Anderson, S. E. (1991). Job satisfaction and organizational commitment as predictors of organizational citizenship and in-role behaviors. Journal of Management, 17(3), 601-617.

Weiss, H. M., \& Cropanzano, R. (1996). Affective events theory: A theoretical discussion of the structure, causes and consequences of affective experiences at work. Research in Organizational Behavior, 18, 1-17.

Ziegler, R., Hagen, B., \& Diehl, M. (2012). Relationship between job satisfaction and job performance: Job ambivalence as a moderator. Journal of Applied Social Psychology, 42(8), 2019-2040. 